\title{
Application of Black Soldier Fly, Hermetia illucens (L., 1758) (Diptera: Stratiomyidae) Larvae to Treat Waste Water
}

\author{
Klaus Doelle ${ }^{1^{*}}$ and Ifeoma Udegbunam ${ }^{2}$ \\ ${ }^{1}$ Department of Chemical Engineering, State University of New York, College of Environmental \\ Science and Forestry, Syracuse, New York, USA. \\ ${ }^{2}$ Department of Natural Science, University of Applied Sciences Bonn-Rhein-Sieg, \\ Grantham-Allee 20, 53757 Sankt Augustin, Germany.
}

\begin{abstract}
Authors' contributions
This work was carried out in collaboration among both authors. Authors KD and IU designed the study, Author IU performed the research and analysis and wrote the first draft of the manuscript. Author KD wrote the final draft and approved the final manuscript.
\end{abstract}

Article Information

DOI: $10.9734 / A R R B / 2021 / v 36 i 230343$

Editor(s):

(1) Dr. Md. Aminur Rahman, Jashore University of Science and Technology, Bangladesh.

Reviewers:

(1) Nikolaos Antonakopoulos, University of Athens, Greece.

(2) Qi Wang, Kunming University of Science and Technology, China. Complete Peer review History: http://www.sdiarticle4.com/review-history/66323

Original Research Article

Received 14 January 2021

Accepted 19 March 2021

Published 26 March 2021

\begin{abstract}
This study investigated the application potential of Black Soldier Fly Larva Hermetia illucens Stratiomyidae: Diptera (L.1758) for wastewater treatment and the removal potential of chemical oxygen demand, ammonia, and phosphorus of and liquid manure residue and municipal waste water containing $1 \%$ solids content.

Black Soldier Fly Larva were found to reduce the concentration of chemical oxygen demand, but unfortunately, increase the concentration of ammonia and phosphorus.

The ability of Black Soldier Fly Larva to feed on organic waste of Liquid manure residue showed that Black Soldier Fly Larva increase their weight by $365 \%$ in a solution with $12 \%$ solids content and by $595 \%$ in a solution having $6 \%$ solids content. The study also showed that Black Soldier Fly Larva have the ability to survive in a solution of $1 \%$ solids content and have the ability to reduce chemical oxygen demand by up to $86.4 \%$ for liquid manure residue and $46.9 \%$ for municipal wastewater after 24 hours. Generally, ammonia increased by $43.9 \%$ for Liquid manure residue and $98.6 \%$ for
\end{abstract}

*Corresponding author: E-mail: kdoelle@esf.edu; 
municipal wastewater. Total phosphorus showed an increase of $11.0 \%$ and $88.6 \%$ increase for liquid manure residue and municipal wastewater respectively over the 8-day study. Transparent environments tend to reduce the COD content more than the dark environment, both for the liquid manure residue $(55.8 \%$ and $65.4 \%)$ and municipal wastewater $(71.5 \%$ and $66.4 \%)$.

Keywords: Black soldier fly larva; Hermetia illucens; manure; waste water treatment.

\section{INTRODUCTION}

Researchers continually try to find ways in which one of human's main problems "Waste Management" can be curbed affordably. Production of organic waste is something that is generated worldwide and its management remains one challenge faced by all countries [1].

Developed countries have a well-thought process of how waste can be managed in contrast to developing/underdeveloped countries. However, one common factor for both developed, developing and underdeveloped countries are discovering ways and processes in which waste management can become affordable and beneficial.

Annual organic waste generation was about 600 million tons within the first decade of this century, and there is a projection that it would be approximately one billion tons by 2025 [2]. Currently, landfills are the most common method used for the disposal of organic wastes, but there are concerns with this approach, in regard to its contribution to global warming, and also soil and water pollution. This goes further to threaten the development and safety of the world, due to poor environmental sanitation [1].

For the reduction of the effects caused by these environmentally problematic methods, and improvement of the world in respect to health, new and affordable mechanisms, such as the use of insects for waste management are currently been explored [3].

The use of insects has been discovered to be a promising and affordable alternative to the management of waste, in which organic waste is converted to insect biomass, which can further serve as animal feed [2].

\subsection{The Black Soldier Fly}

Black soldier fly (Hermetia illucens) (BSF) belong to the insect family Stratiomyidae and occurs throughout most of the Western Hemisphere and the Australian region from Samoa to Hawaii $[4,5]$. It is a non-pest tropical and warm-temperate region insect that is useful for managing large concentrations of waste, such as animal manure [6], food waste, fecal waste etc. into insect biomass. This is because of its low rearing cost, short treatment time, and high efficiency of their larval treatment [7].

The black soldier fly (BSF) is known to be one of the most important insects for bioconversion in the world today because of its short life span, which ranges between 40-45 days [8]. As shown in Fig. 1, the adult BSF lays its eggs (500-900), it takes 4 days for the eggs to metamorphose into larvae, which is known as a voracious stage due to their high rate of food consumption. The larvae undergo 5 instars stages which take place between 13-18 days in its larval stage. The 6th instar is the prepupal stage, which shows a high migratory habit by leaving the food source and further changes to the pupal stage. The adult fly emerges from the pupae afterward. The adult fly lives for 5-8 days, and during this time mating occurs between the male and female BSF and the females lays the eggs and their life cycle continues once again $[8,9]$.

The use of black soldier fly larvae (BSFL) as a bio-converter in waste management is beneficial in that it is a natural end-to-end process [10]. They have large and powerful chewing mouthparts that help them in consumption of organic waste before its decomposition, thereby eliminating odor immediately [11]. Additionally, its ability to grow rapidly and usage in the decomposition of large quantities of rotten waste has made BSFL unique among other insects [8].

Furthermore, it is potential for economical byproducts such as; chitin for chitosan, lipids for fuel substitutes, protein for animal feed and compost (humus). In addition, they have a low pathogen transmit because in their adult stage, mouthparts are absent; therefore, no regurgitation of food occurs.

They reduce or eliminate pest flies breeding, due to their large size, which is relative to that of the houseflies. 


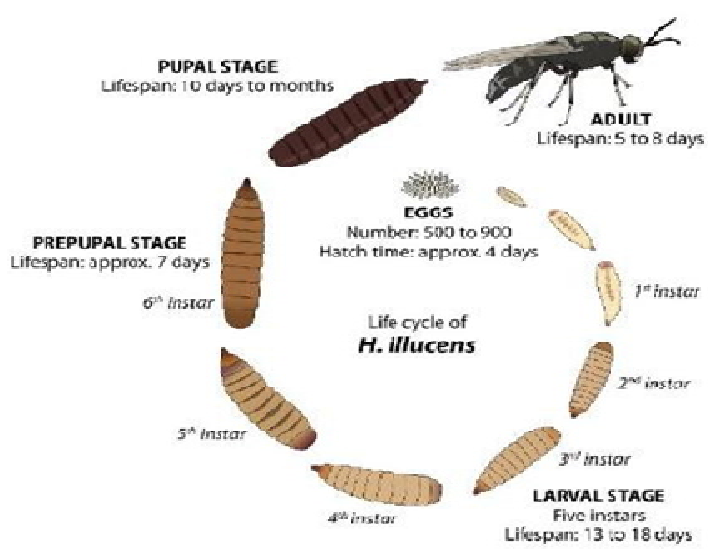

Fig. 1. Life cycle of black soldier fly, Hermetia illucens [8]

Finally, they are rich in protein and fat content, which can be used as fishmeal, meal for pigs, chickens etc. and humans can eat it as well. They also act as insect model for mass production of oil as well [8].

\subsection{Importance of Wastewater Treatment}

Wastewater contains several toxic contents like heavy metals [3], which can have detrimental effect when used as animal feed for fish, pig, poultry etc. and when consumed by humans directly or indirectly. High concentration of chemical oxygen demand (COD), ammonia, and phosphorus in wastewater are also toxic when wastewater is not treated and disposed into water bodies such as rivers, canals, lakes, seas etc. The effect of high concentrations of the aforementioned parameters is that, they lead to eutrophication of the water body, which encourages overgrowth of weeds, algae and cyanobacteria $[12,13]$. Overgrowth of algae can prevent oxygen from reaching into the water; this creates a hypoxic environment which leads to the death of aerobic organism present [13].

In order to improve the water quality of effluent streams, proper measures have to be taken in treatment of wastewater in respect to reduction of COD, ammonia and phosphorus concentration before further use.

The presented study aimed to determine the efficiency of the use of black soldier fly larvae (BSFL) in water remediation in respect to biological nutrient removal such as nitrogen and phosphorus and reduction in chemical oxygen demand (COD) concentration. Two types of wastewater were used; liquid manure residue (LMR) and municipal wastewater (MWW). The first part of the study focused on the ability of the black soldier fly larvae to decompose organic waste present in MWW and LMR used in the study. The second part of the study investigated the survival of BSFL in an aquatic environment, and the third part of the study concentrated COD, ammonia and phosphorus removal ability of BSFL in a daylight, transparent and dark environment.

\section{MATERIALS AND METHODS}

\subsection{Hermetia illucens Larvae}

The Hermetia illucens larvae was bought from VivoteinTM USA. They were kept in solid waste, which serves as a food source for the BSFL. The food source contained $17.5 \%$ protein, $14 \%$ fat, $3.5 \%$ ash, $9340 \mathrm{mg} \mathrm{Kg}-1$ calcium, $3560 \mathrm{mg} \mathrm{Kg}-$ 1 phosphorus and $7.7 \mathrm{mg} \mathrm{Kg}-1$ thiamine. They were $50 \mathrm{BSFL}$ in each of the two containers purchased.

\subsection{Organic Waste Used for the Experimental Study}

Untreated municipal wastewater (MWW) was collected from the primary clarifier of the Village of Minoa wastewater treatment plant, New York State, USA. The liquid manure residue (LMR) was collected from the SUNY - Morrisville diary milk operation, New York State, USA. LMR contained $88 \%$ water $+12 \%$ solid content. The manure solids content was determined using the 
Technical Association of the Pulp and Paper Industry (TAPPI) Test method T412 om-06, "Moisture in pulp, paper and paperboard" [14].

\subsection{PH Measurement}

A pH meter (Accumet AP85) was used in monitoring daily the $\mathrm{pH}$ and temperature of the wastewater sample been experimented during the course of this experiment.

\subsection{Experimental Design}

The experiment study was conducted in several small transparent containers and $30 \mathrm{~mL}$ glass sampling jars. Aluminum foil with punched in holes with a diameter between $2.5 \mathrm{~mm}-5.0 \mathrm{~mm}$ to improve aeration, was used to cover the top of the containers. There was no means created for the prepupae to migrate out of the containers, so they remained in the sample. Several experimental setups in relationship to; BSFL ability to decompose waste, to survive and grow in an aquatic medium, to reduce COD, ammonia, and phosphorus concentration, and finally parameters that can affect the feeding activities of BSFL, was carried out for this study. Wastewater samples were collected daily for the BSFL study investigation.

To verify the exact concentration of Chemical Oxygen Demand (COD), Total Phosphorous (TP) and Ammonia Nitrogen $\left(\mathrm{NH}_{3}-\mathrm{N}\right)$ a HACH DR900 Spectrophotometer and a HACH DRB200 Reactor is used for analysis. The analysis of the collected samples followed HACH Method 8000 [15] for COD using HACH COD TNT plus Vial Test (3-150.0mg/L), HACH Method 10127 [16] for TP using HACH-TNT Reagent Set (1-100.0 $\mathrm{mg} / \mathrm{L}$ ), and $\mathrm{HACH}$ Method 10031 [17] for $\mathrm{NH}_{3}-\mathrm{N}$ using HACH-TNT Reagent Set $(0.4-50.0 \mathrm{mg} / \mathrm{L})$.

\section{RESULTS AND DISCUSSION}

This study aimed to investigate the use of BSFL for wastewater treatment. Before the start of the study, other parameters such as its ability to feed on organic waste, the best aquatic environment for its survival were studied.

\subsection{Growth of BSFL in Organic Waste}

In this study, the ability of BSFL to feed on organic waste of liquid manure residue (LMR) was investigated. Two samples of LMR with $12 \%$ solid content $+88 \% \mathrm{H}_{2} \mathrm{O}$ and $6 \%$ solid content + $94 \% \mathrm{H}_{2} \mathrm{O}$ were studied. Samples were prepared using a $30 \mathrm{~mL}$ clear sampling glass $25 \mathrm{~g}$ of LMR of the above-mentioned specification were used for the study. 10 BSFL were weighed and then inoculated into each sample after preparation. Studies took a time span of about 20 days, afterwards, the weight of BSFL still living and remaining LMR samples were measured.

At the end of the experiment, the number of BSFL alive was 6 for a sample of $12 \%$ solid content $+88 \% \mathrm{H}_{2} \mathrm{O}$ LMR, with LMR waste reduction from $25 \mathrm{~g}$ to $18.63 \mathrm{~g}$ and BSFL increase by $365 \%$ from $0.20 \mathrm{~g}$ to $0.73 \mathrm{~g}$.

Sample with $6 \%$ solid content $+94 \% \mathrm{H} 2 \mathrm{O}$ had 8 living BSFL, LMR was reduced from $25 \mathrm{~g}$ to 17.8 $\mathrm{g}$ and BSFL mass increased by $595 \%$ from 0.21 $\mathrm{g}$ to $1.25 \mathrm{~g}$.

\subsection{BSFL Survival in Aquatic Environ- ment}

Further studies required a liquid environment, the best solid content to water content ratio for LMR had to be studied. BSFL had been known to feed on solid waste in dry or moist environment. Municipal wastewater (MWW) was used serving as a control to observe how BSFL in LMR of varying solid to water content ratio performed.

Several LMR samples were prepared with varying solid to water content; $12 \%$ solid content $+88 \% \mathrm{H} 2 \mathrm{O}, 6 \%$ solid content $+96 \% \mathrm{H} 2 \mathrm{O}, 1 \%$ solid content $+99 \% \mathrm{H} 2 \mathrm{O}$ and the MWW sample.

For this study, a small transparent sampling dish (with lid) and only a small volume of sample (app $3 \mathrm{~mL}$ ) were used. The experiment was done in 6 days and proper observations were noted.

On the 1st and 2nd day, all four samples showed that the BSFL was able to survive. The reason for this are anterior spiracles, which allows the entrance of air in the trachea in aquatic environments [18].

At the 6th day, it was noted that BSFL in the $12 \%$ solid content $+88 \% \mathrm{H} 2 \mathrm{O}$ sample had only 1 BSFL that survived, while $6 \%$ solid content + $96 \% \mathrm{H} 2 \mathrm{O}$ sample had 4 surviving BSFL and $1 \%$ solid content $+99 \% \mathrm{H} 2 \mathrm{O}$ sample had all $5 \mathrm{BSFL}$ still alive. BSFL in MWW all survived just like those in the $1 \%$ solid content $+99 \%$ H2O LMR sample.

For all further studies investigating COD, ammonia and phosphorus concentration the established water to solid content ratio of $1 \%$ 
solid content $+99 \% \mathrm{H}_{2} \mathrm{O}$ was used. LMR provided as the solids content and MWW for dilution to achieve the $1 \%$ solids content.

\subsection{Remediation with BSFL}

The purpose of this first 8-day study was to investigate the influence of BSFL on COD reduction, nitrogen ammonia and phosphorus removal, temperature and $\mathrm{pH}$ values in regard to LMR and MWW. For COD, ammonia, and phosphate, its influent concentrations were measured before inoculation of wastewater sample with BSFL on Day 0 . Subsequent Effluent $(E)$ measurements were done on the remaining 5 days out of 7 days.

Wastewater samples were prepared to $1 \%$ solid content using LMR for the solid fraction and MWW for the liquid fraction. $25 \mathrm{ml}$ of the solution was poured into a $30 \mathrm{~mL}$ test glass jar, as well as $25 \mathrm{~mL}$ of MWW in its own separate sampling jar. Samples were collected for measurement of the influent values for COD, ammonia, and phosphorus using their respective TNT vial reagent set at the beginning of the test.

After sample collection, 56 BSFL were inoculated into both samples. The COD, ammonia and phosphate concentrations (effluent value) were measured daily using a respective TNT vial reagent set, as well as sample temperature and $\mathrm{pH}$ consistently for 4 days. Another set of effluent values were measured on the $7^{\text {th }}$ day. For samples with over range or under range measurement with respect to COD, ammonia, and phosphorus concentration, appropriate dilutions $(1: 10,1: 100)$ were made and re-measured the following day.

For COD a reduction from $9600 \mathrm{mg} / \mathrm{l}$ (influent value) to $1310 \mathrm{mg} / \mathrm{l}(86.4 \%)$ was recorded after 24 hours and further decrease to $647 \mathrm{mg} / \mathrm{l}$ $(93.3 \%)$ at the end of the experiment for $1 \%$ solid content $+99 \%$ H2O LMR sample. MWW recorded a COD reduction from $113 \mathrm{mg} / \mathrm{l}$ (influent value) to $60 \mathrm{mg} / \mathrm{l}(46.9 \%)$ after 24 hours. COD concentration increased for the $2^{\text {nd }}$ and $3^{\text {rd }}$ day for MWW to $129.0 \mathrm{mg} / \mathrm{l}$., but no further increase was noted afterward. The COD content was $86.5 \mathrm{mg} / \mathrm{l}$ which translates into a $24.5 \%$ reduction for the MWW. Ammonia concentration decreased from $28 \mathrm{mg} / \mathrm{l}$ (influent value) to 19.1 $\mathrm{mg} / \mathrm{l}$ after 24 hours, but then increased to $40.3 \mathrm{mg} /$ at the $7^{\text {th }}$ day for the LMR sample. Sample of MWW showed a continual increase of ammonia from $21.3 \mathrm{mg} / \mathrm{l}$ (influent value) to $42.3 \mathrm{mg} / \mathrm{l}$ $(98.6 \%)$ at the end of the experiment.

Total phosphorus, which was determined by the concentration of phosphate, showed fluctuations in its values for both LMR and MWW. In general an increase was noted. MWW sample phosphate increased from $7.9 \mathrm{mg} / \mathrm{l}$ to 14.9 $\mathrm{mg} / \mathrm{l}(88.6 \%)$ and from $49 \mathrm{mg} / \mathrm{l}$ to 54.4 $\mathrm{mg} / \mathrm{l}(11.0 \%)$ for LMR sample at the end of the study.

The $\mathrm{pH}$ ranges between $7.08-7.95$ and temperatures between 16.5 and 18.3 were recorded.

Table 1. COD, ammonia, phosphate concentration, $\mathrm{pH}$ and temperature $\left[{ }^{\circ} \mathrm{C}\right]$

\begin{tabular}{lllllll}
\hline Days & Samples & $\begin{array}{c}\text { Phosphate } \\
{[\mathbf{m g} / \mathbf{l}]}\end{array}$ & $\begin{array}{l}\text { Ammonia } \\
{[\mathbf{m g} / \mathbf{l}]}\end{array}$ & $\begin{array}{l}\text { COD } \\
{[\mathbf{m g} / \mathbf{l}]}\end{array}$ & $\mathbf{p H}$ & $\begin{array}{l}\text { Temp } \\
{\left[{ }^{\circ} \mathbf{C}\right]}\end{array}$ \\
\hline 0 & LMR & 49.0 & 28.0 & 9600.0 & 7.08 & 17.6 \\
& MWW & 7.9 & 21.3 & 113.0 & 7.64 & 18.0 \\
1 & LMR & 50.4 & 19.1 & 1310.0 & 7.25 & 18.2 \\
& MWW & 11.2 & 24.3 & 60.0 & 7.64 & 18.4 \\
2 & LMR & 49.8 & 24.2 & 759.0 & 7.58 & 17.1 \\
& MWW & 11.9 & 29.9 & 129.5 & 7.58 & 17.2 \\
3 & LMR & 48.2 & 30.5 & 709.0 & 7.56 & 16.6 \\
& MWW & 10.7 & 34.0 & 129.5 & 7.69 & 16.5 \\
4 & LMR & 48.2 & 33.5 & 640.0 & 7.80 & 17.2 \\
& MWW & 10.8 & 34.6 & 98.0 & 7.90 & 17.2 \\
7 & LMR & 54.4 & 40.3 & 647.0 & 7.85 & 18.2 \\
& MWW & 14.9 & 42.3 & 86.5 & 7.95 & 18.3 \\
\hline
\end{tabular}




\subsection{Effect of Light on BSFL Ability to Treat Wastewater}

The effect of light on BSFL ability to reduce COD, and remove ammonia and phosphorus was investigated by creating a dark and transparent environment using dark and transparent jars. The study duration was 8 days.

Two sets each of experiment was carried out for both $1 \%$ solid content $+99 \%$ H2O LMR and MWW with dark and transparent $30 \mathrm{~mL}$ sampling glass jars. The dark jars were covered by white adhesives paper tapes and a black marker to paint on them. Influent value (0-day sample) of COD, ammonia, and phosphate was measured before inoculation with BSFL. 28 BSFL were inoculated into each set of samples. It should be noted that for this study and the previous study, sampling glass jars were always covered with aluminum foil, with tiny holes for the passage of oxygen and it was only during the collection of samples for measurement that this foil was removed. Concentrations were measured with the TNT vial reagent set for ammonia, phosphate, and COD. The study took place for 8 days. After 24 hours of study, COD concentration reduced from $4370.0 \mathrm{mg} / \mathrm{l}$ to $2980.0 \mathrm{mg} / \mathrm{l}(38.7 \%)$ in the dark environment and to $2680.0 \mathrm{mg} / \mathrm{l}$ $(39.5 \%)$ in the transparent environment using a $1 \%$ solution of LMR. After 8 days the COD was reduced to $1930 \mathrm{mg} / \mathrm{l}$ for the dark environment and $1510 \mathrm{mg} / \mathrm{l}$ for the transparent environment (55.8\% and $65.4 \%)$ for the LMR.

The MWW sample recorded a COD reduction from $147.4 \mathrm{mg} / \mathrm{l}$ to $86.0 \mathrm{mg} / \mathrm{l}(41.7 \%)$ for dark environment and $104.0 \mathrm{mg} / \mathrm{l}$ (29.4\%) for transparent environment. After 8 days the COD was reduced to $42.0 \mathrm{mg} / \mathrm{l}$ and $49.6 \mathrm{mg} / \mathrm{l}(71.5 \%$ and $66.4 \%$ ) for the MWW.

The concentration of ammonia reduced from $83.0 \mathrm{mg} / \mathrm{l}$ to below $61.0 \mathrm{mg} / \mathrm{l}(26.5 \%)$ and 50.0 (39.8\%) mg/l for LMR samples, while MWW increase from 17.0 to over $27.5 \mathrm{mg} / \mathrm{l}$ and $30 \mathrm{mg} / \mathrm{l}$ $(50.0 \%$ and $75.5 \%)$ for the dark and transparent environment respectively.

Table 2. COD, ammonia, phosphate concentration, ph and temperature $\left[{ }^{\circ} \mathrm{C}\right]$ in $\mathrm{MWW}$ and $1 \%$ SC LMR for dark and transparent jar

\begin{tabular}{|c|c|c|c|c|c|c|}
\hline Days & Samples & $\begin{array}{l}\text { Phosphate } \\
{[\mathrm{mg} / \mathrm{l}]}\end{array}$ & $\begin{array}{l}\text { Ammonia } \\
{[\mathrm{mg} / \mathrm{l}]}\end{array}$ & $\begin{array}{l}\text { COD } \\
{[\mathrm{mg} / \mathrm{l}]}\end{array}$ & $\mathrm{pH}$ & Temp. $\left[{ }^{\circ} \mathrm{C}\right]$ \\
\hline \multirow[t]{2}{*}{0} & LMR & 135.0 & 83.0 & 4370.0 & 7.41 & 15.7 \\
\hline & MWW & 5.9 & 17.0 & 147.4 & 7.47 & 13.2 \\
\hline \multirow[t]{4}{*}{1} & LMR Dark & 111.0 & 65.0 & 2980.0 & 8.68 & 17.5 \\
\hline & transparent & 104.0 & 62.0 & 2680.0 & 7.66 & 17.1 \\
\hline & MWW Dark & 4.5 & 15.2 & 86.0 & 8.30 & 16.3 \\
\hline & transparent & 3.0 & 16.3 & 104.0 & 8.19 & 16.5 \\
\hline \multirow[t]{4}{*}{2} & LMR Dark & 109.0 & 66.0 & 2520.0 & 8.11 & 14.9 \\
\hline & transparent & 112.0 & 66.0 & 3080.0 & 8.56 & 15.1 \\
\hline & MWW Dark & 8.2 & 19.9 & 77.0 & 8.51 & 15.5 \\
\hline & transparent & 7.7 & 17.4 & 66.0 & 8.45 & 15.5 \\
\hline \multirow[t]{4}{*}{4} & LMR Dark & 95.0 & 46.0 & 1010.0 & 8.08 & 14.9 \\
\hline & transparent & 92.0 & 49.0 & 2180.0 & 8.17 & 14.4 \\
\hline & MWW Dark & 10.0 & 21.9 & 106.7 & 8.37 & 15.0 \\
\hline & transparent & 9.7 & 22.5 & 91.1 & 7.94 & 14.9 \\
\hline \multirow[t]{4}{*}{6} & LMR Dark & $* *$ & 61.0 & 2290.0 & 8.62 & 17.7 \\
\hline & transparent & ** & 57.0 & 1740.0 & 8.19 & 17.7 \\
\hline & MWW Dark & 11.0 & 27.5 & 49.3 & 8.63 & 17.8 \\
\hline & transparent & 13.1 & 30.0 & 50.6 & 8.57 & 17.8 \\
\hline \multirow[t]{4}{*}{7} & LMR Dark & 88.8 & * & 1930.0 & 8.82 & 18.6 \\
\hline & transparent & 95.5 & 50.0 & 1510.0 & 8.55 & 18.3 \\
\hline & MWW Dark & * & & 42.0 & 8.64 & 18.8 \\
\hline & transparent & * & & 49.6 & 8.64 & 18.7 \\
\hline
\end{tabular}


Ammonia concentration was reduced from 135.0 $\mathrm{mg} / \mathrm{l}$ to $88.5 \mathrm{mg} / \mathrm{l}$ and $104.0 \mathrm{mg} / \mathrm{l}(34.4 \%$ and $\%$ $22.9 \%$ ) for LMR in dark and transparent environment respectively. MWW samples showed an increase in phosphate from $5.9 \mathrm{mg} / \mathrm{l}$ to $11.0 \mathrm{mg} / \mathrm{l}$ and $13.1 \mathrm{mg} / \mathrm{l}(86.4 \%$ and $122.0 \%$ ) for the dark and transparent environment respectively.

Phosphate concentration was reduced from $135.0 \mathrm{mg} / \mathrm{l}$ to $88.5 \mathrm{mg} / \mathrm{l}$ and $104.0 \mathrm{mg} / \mathrm{l}(34.4 \%$ and $22.9 \%$ ) for LMR in dark and transparent environment respectively. MWW samples showed an increase in phosphate from $5.9 \mathrm{mg} / \mathrm{l}$ to $11.0 \mathrm{mg} / \mathrm{l}$ and $13.1 \mathrm{mg} / \mathrm{l}(86.4 \%$ and $122.0 \%$ ) for the dark and transparent environment respectively.

Temperature range of $13.2^{\circ} \mathrm{C}$ to $18.8^{\circ} \mathrm{C}$ and $\mathrm{pH}$ range of 7.41 to 8.82 was recorded during the study period.

There were some fluctuations with the concentration values recorded during this study, as can be seen in the Table 2 .

\section{CONCLUSION}

This study confirms the application potential of BSFL in solid waste management and the survival of BSFL in dilute environment containing $1 \%$ solids content. In respect to COD, ammonia, and phosphorus reduction for solutions of up $1 \%$ solid content $+99 \% \mathrm{H} 2 \mathrm{O}$ and MWW, BSFL were found to reduce the concentration of COD, but unfortunately, increase the concentration of ammonia and phosphorus.

The ability of BSFL to feed on organic waste of LMR showed that BSFL increases their weight by $365 \%(0.20 \mathrm{~g}$ to $0.73 \mathrm{~g})$ in LMR having $12 \%$ solids content while BSFL weight increased by $595 \%(0.21 \mathrm{~g}$ to $1.25 \mathrm{~g})$ in LMR having $6 \%$ solids content.

A study of BSFL in LMR solutions with $6 \%$ and $1 \%$ solids content showed that BSFL has the ability to survive and in solutions with a low solids content.

Under daylight, results show that COD can be reduced by up to $86.4 \%$ for LMR and up to $46.9 \%$ for MWW after 24 hours. Generally, ammonia increased by $43.9 \%$ for LMR and $98.6 \%$ in MWW, while for total phosphorus, showed an increase of $11 \%$ and $88.6 \%$ increase for LMR and MWW respectively over the 8-day study. Transparent environments tend to reduce the COD content more than dark environments.

This study investigated the application potential of Black Soldier Fly Larva Hermetia illucens Stratiomyidae: Diptera (L.1758) for wastewater treatment and the removal potential of chemical oxygen demand, ammonia, and phosphorus of and liquid manure residue and municipal wastewater containing $1 \%$ solids content.

Black Soldier Fly Larva were found to reduce the concentration of chemical oxygen demand, but unfortunately, increase the concentration of ammonia and phosphorus.

The ability of Black Soldier Fly Larva to feed on organic waste of Liquid manure residue showed that Black Soldier Fly Larva increase their weight by $365 \%$ in a solution with $12 \%$ solids content and by $595 \%$ in a solution having $6 \%$ solids content. The study also showed that Black Soldier Fly Larva have the ability to survive in a solution of $1 \%$ solids content.

Results show that chemical oxygen demand can be reduced by up to $86.4 \%$ for liquid manure residue and $46.9 \%$ for municipal wastewater after 24 hours. Generally, ammonia increased by $43.9 \%$ for Liquid manure residue and $98.6 \%$ for municipal wastewater. Total phosphorus showed an increase of $11.0 \%$ and $88.6 \%$ increase for liquid manure residue and municipal wastewater respectively over the 8-day study. Transparent environments tend to reduce the COD content more than the dark environment, both for the liquid manure residue $(55.8 \%$ and $65.4 \%)$ and the municipal wastewater $(71.5 \%$ and $66.4 \%)$.

$29.3 \%$ for phosphate, and $39.8 \%$ for ammonia in the LMR sample of the transparent jar. MWW sample showed a $71.5 \%$ and $66.4 \%$ reduction in COD for dark and transparent jar respectively. Phosphate and ammonia.

Ammonia concentration was reduced $(34.4 \%$ and $22.9 \%$ ) for liquid manure residue, while municipal wastewater samples showed an increase $86.4 \%$ and $122.0 \%$ ) for the dark and transparent environment respectively.

Ammonia concentration reduced from $50.0 \%$ and $75.5 \%$ for the dark and transparent environment, respectively. 
Ammonia concentration was reduced from $135.0 \mathrm{mg} / \mathrm{l}$ to $88.5 \mathrm{mg} / \mathrm{l}$ and $104.0 \mathrm{mg} / \mathrm{l}(34.4 \%$ and 22.9\%) for LMR in dark and transparent environment, respectively. MWW samples showed an increase in Phosphate decreased for liquid manure residue $86.4 \%$ and $122.0 \%$ for the dark and transparent environment respectively but increased for municipal wastewater $86.4 \%$ and $122.0 \%$ for the dark and transparent environment respectively.

\section{ACKNOWLEDGEMENTS}

The authors are grateful for the support provided by ESF-TRINITY Institute at SUNY-ESF.

\section{COMPETING INTERESTS}

Authors have declared that no competing interests exist.

\section{REFERENCES}

1. Sarpong D, Oduro-Kwarteng S, Gyasi SF, Buamah R, Donkor E, Awuah E, et al. Bio degradation by composting of municipal organic solid waste into organic fertilizer using the black soldier fly (Hermetia illucens) (Diptera: Stratiomyidae) larvae. International Journal of Recycling of Organic Waste in Agriculture. 2019;8:45-54.

2. Liu Z, Minor M, Morel PCH, Najar-Rodriguez AJ. Bioconversion of three organic wastes by black soldier fly (Diptera: Stratiomyidae) larvae. Environmental Entomology. 2018;47(6):1609-1617.

3. Diener S, Studt Solano NM, Roa Gutiérrez F, Zurbrügg C, Tockner K. Biological treatment of municipal organic waste using black soldier fly larvae. Waste and Biomass Valorization. 2011;2(4):357363.

4. Oliveira F, Doelle K, List R. Assessment of diptera: Stratiomyidae, genus Hermetia illucens (L., 1758). Journal of Entomology and Zoology Studies. 2015;3(5):147152.

5. Roskosny R. A biosystematics study of the European stratiomyidae (diptera). Series Entomologica. 2019; 2.

6. Sheppard DC, Tomberlin JK, Joyce JA, Kiser BC, Sumner SM. Rearing methods for the black soldier fly (Diptera: Stratiomyidae). Journal of Medical Entomology. 2002;39(4):695-698.
7. Cai M, Hu R, Zhang K, Ma S, Zheng L, Yu Z, Zhang J. Resistance of black soldier fly (diptera: stratiomyidae) larvae to combined heavy metals and potential application in municipal sewage sludge treatment. Environmental Science and Pollution Research. 2018;25(2):1559 1567.

8. De Smet J, Wynants $\mathrm{E}$, Cos $\mathrm{P}$, Van Campenhout L. Microbial community dynamics during rearing of Black soldier fly larvae (Hermetia illucens) and impact on exploitation potential. Applied and Environmental Microbiology. 2019;84(9):117.

9. Newton L, Sheppard C, Watson DW, Burtle $\mathrm{G}$, Dove R. Using the black soldier fly, Hermetia illucens, as a value-added tool for the management of swine manure. Waste Management Programs. North Carolina State University; 2005.

10. Jonas Levi A, Shaltiel L, Danai O, Martinez JII. Decomposition of waste by black soldier fly larvae - Hermetia illucens. Aste by black soldier fly larvae can be controlled; 2016.

11. Rindhe SN, Chatli MK, Wagh RV, Kaur A, Mehta N, Kumar $P$, et al. Black soldier fly: A new vista for waste management and animal feed. International Journal of Current Microbiology and Applied Sciences. 2019;8(1):1329-1342.

12. Kladitis G, Diamantis $N$, Grigoropoulou $H$. Ammonia and phosphorous removal in municipal waste water treatment plant with extended aeration. Global Nest Journal. The International Journal. 2018;1(1):4753.

13. Doelle K, Peluso C. Earthworm and algae species in a trickling filter. British Journal of Advances in Biology and Biotechnology (BJABB). 2015;3(3):132-138.

14. TAPPI T412 om-06. Moisture in pulp, paper and paperboard; 2018.

15. HACH method 8000: Oxygen demand, chemical.

Available:https://www.hach.com/dr1900portable-spectrophotometer/productparameter-reagent?id=18915675456

16. HACH Method 10127: Phosphorus, Total. Available:https://www.hach.com/dr1900portable-spectrophotometer/productparameter-reagent?id=18915675456

17. HACH Method 10031: Nitrogen Ammonia. Available:https://www.hach.com/dr1900portable-spectrophotometer/productparameter-reagent?id=18915675456 
18. Oliveira F, Doelle K, Smith RP. External

Research and Review in Biology (ARRB). Morphology of Hermetia illucens (L., 1758). 2016;9(5):1-10.

Based on electron microscopy. Annual

(C) 2021 Doelle and Udegbunam; This is an Open Access article distributed under the terms of the Creative Commons Attribution License (http://creativecommons.org/licenses/by/4.0), which permits unrestricted use, distribution, and reproduction in any medium, provided the original work is properly cited.

Peer-review history:

The peer review history for this paper can be accessed here: http://www.sdiarticle4.com/review-history/66323 